\title{
Relatos imperiais: a literatura de viagem entre a política e a ciência na Espanha, França e Inglaterra (1680-1780) ${ }^{1}$
}

Imperial Narratives: Travel Literature between Politics and Science in Spain, France and England (1680-1780)

\section{Rogelio C. Paredes \\ Professor da Cátedra de História Moderna da Universidade de Buenos Aires (UBA - Buenos Aires/Argentina). e-mail: rcparedes@fibertel.com.ar}

\begin{abstract}
Resumo
A literatura de viagem surgiu como uma prática cultural associada à expansão marítima europeia. Das histórias curiosas e cheias de aventuras das primeiras empresas lusitanas e castelhanas na África, no Oriente Médio e no Extremo Oriente, o gênero passou a consolidar-se como um avanço do saber, na medida em que a Revolução Científica fixava padrões cada vez mais estáveis de verdade, verossimilhança e objetividade. Entre o final do século XVII e o final do século XVIII, as potências coloniais envolvidas em uma intensa competição pelo domínio dos mares e territórios ultramarinos procuraram legitimar seus projetos de expansão em empresas sustentadas em suas aspirações para aperfeiçoar o saber ilustrado da época, orientado a construir um conhecimento universal sobre o planeta, suas espécies vegetais e animais e suas sociedades e culturas. Com base nos relatos de viagens da época existentes na Biblioteca do Museu Etnográfico de Buenos Aires, o trabalho busca identificar as características dessas empresas e obras em relação ao contexto internacional, à política imperial dos Estados e às condições socioculturais do público interessado nessas obras, com o objetivo de assinalar as semelhanças e diferenças entre elas.
\end{abstract}

\section{Abstract}

Travel literature emerged as a cultural practice associated to overseas European expansion. From being at first associated to the curious stories and adventures of the first Portuguese and Spanish voyages to Africa as well as to the Middle and the Far East, travel literature consolidated as a synonym of knowledge just as the Scientific Revolution established increasingly stable patterns of truth, authenticity and objectivity. Between the end of the XVIIth century and the end of the XVIIIth century, colonial powers, which were involved in an intense struggle to control the seas and its overseas territories, sought to legitimate their expansionist projects by organizing expeditions based on the principles of the Enlightenment which were held at the time. They thus oriented their expansionist projects so as to gather universal knowledge on the planet, its vegetable and animal species, and its societies and cultures. By means of analyzing the collection of travel literature kept at the library of the Buenos Aires Ethnographic Museum, the present essay seeks to identify the characteristics of these expeditions and the narratives that described them in order to connect them to the international context in which they were produced, the imperial policy of each State and the similarities and differences of the cultural and social conditions of the audiences interested in them. 
Palavras-chave

literatura de viagem, expansão ultramarina, Ilustração, Ciência, competição colonial

\section{Keywords}

voyage literature, overseas expansion, Enlightenment, Science, colonial rivalry

2

WALLERSTEIN, Immanuel. El moderno sistema mundial. Vol.I: La agricultura capitalista y los orígenes de la economia-mundo en el siglo XVI. México: Siglo XXI Editores, 1979; Vol.II:EI mercantilismo y la consolidación de la economía mundo europea, 1600-1750. México: Siglo XXI Editores, 1984
REI, Dario La revolución científica. Barcelona: Icaria, 1978; CROMBIE, Alistair C. Historia de la ciencia de San Agustín a Galileo. Tomo II - La ciencia en la Baja Edad Media y comienzos de la Edad Moderna, Siglos XIII al XVII. Madrid: Alianza, 2007. Uma perspectiva crítica sobre o conceito e sua aplicação se encontra em SHAPIN, Steve. La Revolución Científica. Una interpretación alternativa. Barcelona: Paidós, 2000

4

CHARTIER, Roger: Espacio público, crítica y desacralización en el siglo XVIII. Los orígenes culturales de la Revolución Francesa. Barcelona: Gedisa, 1995. Do mesmo autor, ver El orden de los libros. Lectores, autores, bibliotecas entre los libros XIV y XVIII. 2a edição. Barcelona: Gedisa, 1996, e Libros, lecturas y lectores en la Edad Moderna. Madrid: Alianza, 1994.

BITTERLI, Urs. Los "salvajes" y los "civilizados": el encuentro de Europa y Ultramar. México: Fondo de Cultura Económica, 1982; e PRATT, Mary L. Ojos imperiales: literatura de viajes y transculturación. Bernal: Universidad de Quilmes, 1992. Trata-se de duas perspectivas opostas sobre a relação entre ciência e expansão colonial no século XVIII.

\section{Circum-navegação, ciência e império universal}

0 século XVIII foi marcado por disputas imperiais, polêmicas científicas e filosóficas e circum-navegações do globo. Durante os primeiros séculos da modernidade, aproximadamente entre 1450 e 1715, as potências marítimas da Europa disputavam o controle de espaços coloniais abertos à exploração com o propósito de convertê-los em áreas de exploração de recursos e, eventualmente, em mercados consumidores de bens manufaturados produzidos nas metrópoles. ${ }^{2}$ No entanto, durante o século XVIII, o aumento das demandas comerciais de produtos ultramarinos, a crescente ascensão dos setores empresariais e de navegação vinculados aos circuitos coloniais e à difusão das conquistas da Revolução Científica imprimiram às viagens dessa etapa e aos seus relatos uma marca que os diferencia claramente daqueles dos séculos anteriores.

A ampliação do poder naval britânico e sua competição com o poderio naval francês seria resolvida ao longo do século não só em termos de domínio militar e econômico, mas também na expansão e consolidação de uma ciência cujo horizonte consistia principalmente na formação de um novo conhecimento do mundo. A circum-navegação converteu-se em seu emblema e sua empresa mais significativa.

A literatura de viagem surgiu inicialmente como uma prática sociocultural originada na experiência da expansão marítima europeia. Desde as histórias curiosas e cheias de aventuras das primeiras empresas lusitanas e castelhanas na África, no Oriente Médio e no Extremo Oriente, o gênero passou a consolidar-se mais e mais como um avanço do novo saber sobre a natureza, o homem e o mundo, à medida que a Revolução Científica fixava padrões cada vez mais estáveis e regulares de verdade, credibilidade e objetividade. ${ }^{3} 0$ aumento de uma cultura impressa que, por sua parte, foi uma das características da modernidade, ampliou o número dos leitores e, como ter sido mostrado por autores como Roger Chartier, ${ }_{1}^{4}$ foi dominando com sua crescente autoridade o âmbito das polêmicas científicas e políticas, enquanto crescia, ademais, o publico leitor - processo mais avançado na Grã-Bretanha que no continente, e na França mais que em outros países.

Entre o final do século XVII e fins do século XVIII, as potências coloniais envolvidas em uma intensa competição pelo domínio de mares e territórios ultramarinos procuraram legitimar sua projetos de expansão militar, diplomática e produtiva em empresas que buscavam aperfeiçoar o conhecimento ilustrado, destinadas a constituir um conhecimento universal sobre o planeta, suas espécies vegetais e animais e suas sociedades e culturas. A pretensão de um saber "objetivo", desinteressado e universal escondia a intensificação das disputas territoriais e econômicas no ultramar e as polêmicas de cientistas e intelectuais sobre as pretensas hegemonias de saber e poder dentro das academias e dos círculos intelectuais. ${ }^{5} \mathrm{~A}$ reiteração das viagens de circum-navegação - no caso da Inglaterra e da 
6

A Coleção dos Viageiros da Biblioteca do Museu Etnográfico de Buenos Aires contém 584 livros editados nos séculos XVI, XVII, XVIII e XIX, formando um acervo especialmente dedicado às descrições da Patagônia, do Estreito de Magalhães, das Ilhas Malvinas e outras áreas.

WOLF, Eric. Europa y la gente sin historia. México: Fondo de Cultura Económica, 1987, capitulo VIII.

8

WALLERSTEIN, Immanuel. El moderno sistema mundial... Op. Cit., tomo II, capitulo I.
Espanha - e a apresentação das mesmas como a grande empresa de uma monarquia em crise - no caso da França - demonstram, na verdade, a aspiração global, universal, de dominar as rotas de todos os mares como uma manifestação concreta de domínio político e militar e da tradução desse domínio no campo da ciência.

As aspirações políticas, econômicas e intelectuais que contribuiram para multiplicar as viagens científicas e não científicas durante o século XVIII e a escrita e publicação dos relatos de viagem também impulsionaram o aumento do público leitor dessa literatura. Com base nas edições de época desses relatos existentes na Biblioteca do Museu Etnográfico de Buenos Aires $^{6}$, este trabalho procura identificar as caracteristicas dessas empresas e obras tanto em relação com os mutantes contextos internacionais como com a política imperial dos Estados e com as condições sócio culturais do público interessado nessas obras, com o propósito de observar semelhanças e diferenças entre elas.

Para além de um interesse genérico pelas empresas ultramarinas, por seus benefícios comerciais ou produtivos, pelas expectativas compartilhadas de estender e aprofundar o domínio sobre territórios conhecidos ou desconhecidos por parte das potências europeias, o certo é que as diferenças na escrita, publicação, circulação, leitura e crítica da literatura de viagem foram um motor que impulsionou essa empresa e desempenhou um papel determinante, junto com outros, em seus efeitos, conquistas e limitações. Isso se explica pela configuração social de cada um dos países em questão, pelo desenvolvimento dos interesses comerciais em relação a ela e pelo desenvolvimento da indústria editorial e do grau de alfabetização e de interesse do público leitor.

Assim, a descrição e a eventual análise dos materiais bibliográficos existentes no Museu Etnográfico expressam tendências mais amplas e instaladas nas sociedades das potências coloniais que disputavam, tanto no campo militar como no econômico e científico, a primazia das configurações coloniais.

\section{Grã-Bretanha, França e Espanha em disputa (1550-1790)}

Com o crescimento dos impérios coloniais, as potências navais e os setores sociais ligados a eles podem ser considerados em uma tendência geral dos séculos iniciais da modernidade. Depois da etapa de expansão marítima iniciada pelos portugueses no século XV e consolidada com a chegada deles à Índia, à China e ao Japão, espanhóis, ingleses, holandeses e franceses adentraram os mares para participar dos benefícios da exploração dos recursos ultramarinos e de sua comercialização. ${ }^{7}$ A instalação de assentamentos coloniais na América e na Indonésia levaram alguns autores a ver na Guerra dos Trinta Anos (1618-1648) o primeiro conflito mundial na disputa entre Espanha e Holanda pelo controle do comércio mundial. ${ }^{8}$

A instalação das potências europeias em áreas ultramarinas e a disputa pelos mares daria origem a um processo cujas etapas principais se podem resenhar brevemente. A expansão portuguesa no Atlântico e no Índico abriu o caminho para a instalação dos espanhóis na América, e o desenvolvimento das explorações coloniais permitiu o ingresso, na Europa, de fluxos importantes de metais preciosos e produtos coloniais, entre meados do século XV e a segunda metade de século XVI. França e Inglaterra estavam prontas para disputar o monopólio comercial alcançado pelas potências ibéricas. Os franceses começaram a desembarcar no Brasil e, mais tarde, 
John. España bajo los Austria. Vol.2: España y América (1598-1700). Barcelona: Península, 1975. p.108. tentaram colonizá-lo, da mesma forma que à Flórida (1555). Os ingleses, por sua vez, iniciaram uma série de ações para abrir o comércio colonial aos seus próprios comerciantes e para desviar o fluxo de metais preciosos da Espanha em proveito próprio, pela ação de corsários licenciados pela coroa, ao mesmo tempo em que tentava instalar colônias na Virgínia, sob o reinado de Elizabeth I (1556-1603). 0 ritmo e a intensidade do conflito com a Espanha ampliaram-se com o aumento das disputas dinásticas e religiosas da Contrarreforma e da expansão do calvinismo. A anexação de Portugal a Castela ocorrida durante o reinado de Filipe II (1580) impulsionou as Províncias Unidas, recém-independentes da monarquia espanhola, a assaltar o comércio e as instalações de Portugal, primeiro na África e, em seguida, no Oriente e no Brasil. A derrota decisiva da frota espanhola na baía de Matanzas, em 1628, diante de uma frota holandesa sob o comando do almirante Piet Heyn ${ }^{9}$, produziu uma mudança significativa na área: 0 vazio do domínio espanhol e a presença de colonos e aventureiros europeus nas ilhas do Caribe provocaram a ingerência das potências inimigas na região e, algumas décadas mais tarde, uma ofensiva geral dos bucaneiros e piratas sobre as instalações espanholas nas costas e ilhas da América Central, e 0 ataque contínuo de seu tráfico colonial, situação agravada pela conquista inglesa da Jamaica durante a República de Cromwell (1655).

A situação de fraqueza espanhola se acentuou com a chegada de Luis XIV (1661-1715) ao trono: enquanto a Inglaterra continuou seus ataques no ultramar, a potência territorial francesa procurou assenhorar-se dos Países Baixos espanhóis e do Franco Condado. Esta situação chegou ao seu ponto culminante durante a Guerra da Liga de Augsburgo (16891697), na qual o "Rei Sol" assumiu o desafio de enfrentar seus adversários marítimos, inaugurando um período de expansão francesa no Atlântico Sul que completava, de certa forma, os esforços coloniais realizados na exploração da Louisiana e de Quebec. Nesta conjuntura, e após a eclosão da Guerra de Sucessão Espanhola (1702-1713), o poder francês se viu obrigado a desenvolver seu interesse pela navegação nas costas americanas, tanto por razões militares - a defesa das possessões coloniais espanholas, agora parte do reino de um governante da dinastia, Felipe de Anjou V da Espanha - como pela necessidade de fornecer a essas colônias os produtos do comércio europeu, comércio do qual a metrópole espanhola tinha sido deslocada quase que por completo.

Com a Paz de Utrecht (1713), a Espanha, além de ocupar um claro segundo plano nas disputas do ultramar, consagrou a posição de aliança continental com França e concedeu o domínio dos mares à Inglaterra, agora reforçada pela consolidação da união com a Escócia (1707). A superioridade naval inglesa tinha sido ratificada durante a Guerra de Sucessão com a circum-navegação do corsário Woodes Rogers (1708-1711), e a França finalmente percebeu o peso e a importância do desafio que enfrentaria para enfraquecer o domínio inglês pela aquisição de benefícios navais indispensáveis. 0 comércio de escravos concedido como resultado da Paz de Utrecht à Companhia Inglesa da África aguçou o interesse britânico pelo Atlântico Sul, indispensável em sua rota até o Brasil, o Rio da Prata e o Estreito de Magalhães, novos mercados e rotas de acesso fundamentais ao litoral americano. A França também desenvolvia seus interesses na América, e a competição no cenário europeu permitiu aos britânicos tomar a dianteira durante as guerras de Filipe $V$ pelo Reino de Nápoles (1719-1720), a Guerra de Sucessão Polonesa (1730-1733) e, de forma decisiva, no decurso 
10

Sobre a conjuntura internacional do século XVIII e seu desenvolvimento posterior, ver LYNN, John A. Rivalidad internacional y guerra. In: BLANNING, Timothy (editor). EI Siglo XVIII: Historia de Europa de Oxford. Barcelona: Crítica, 2002. p.188-228.

11

As expedições de Miguel López de Legazpi e Felipe de Sakcedo (1564-1565) completaram o trajeto de ida e volta entre Nova Espanha e as Filipinas; e as de Alvaro de Mendaña e Pedro Fernández de Quirós (1567-1605) tornaram possivel a navegação entre o Peru e as Filipinas. 0 Estreito de Magalhães fora reconhecido desde as costas chilenas por Juan Ladrillero (1557-1558). dos conflitos da Sucessão Austríaca (combinado com enfrentamentos nas fronteiras coloniais no Canadá e com a Espanha) entre 1738-1748 e, finalmente, da Guerra dos Sete Anos (1756-1763), que terminou de arrebatar aos franceses todas as suas possessões em Quebec, na Louisiana e na Índia e consolidou o controle Inglês sobre os mares por dois séculos. ${ }^{10}$

Depois das viagens de exploração das costas do Oceano Pacífico e do descobrimento pelos espanhóis do sistema de ventos e correntes marítimas entre América e Filipinas, a rota pelo Estreito de Magalhães foi lentamente abandonada. ${ }^{11} \mathrm{~A}$ Espanha não realizou novos avanços nos séculos $\mathrm{XVII}$ e XVIII no domínio militar e no conhecimento cientifico nessa região, enquanto suas rivais Inglaterra e Holanda procuraram legitimar sua dominação nessa zona percorrendo as rotas deixadas pelos espanhóis e outras novas - como a descoberta pela viagem de Scouten e Le Maire entre as ilhas da Terra do Fogo e de Los Estados em sua expedição de 1615-1617 - como único acesso possivel para eles aos Mares do Sul, suas riquezas mineiras e os mercados orientais.

Embora relegada a um papel menor após a Paz de Utrecht, a Espanha realizou um esforço significativo para acompanhar, em parte, a luta de sua aliada dinástica e ratificar seu papel como potência colonial de primeira ordem, dona dos maiores estabelecimentos coloniais da América. 0 variado e multiforme conjunto de medidas econômicas, administrativas, militares e culturais conhecido como Reformas Borbônicas também originou duas das maiores contribuições da Ilustração espanhola nos planos geográfico e científico: as missões políticas, diplomáticas e exploratórias de Félix de Azara, no Rio da Prata e no Paraguai (1781-1801), e a circum-navegação de Alejandro Malaspina (1788-1794), cuja relevância posterior seria apreciada pelo público europeu ao longo de todo o século XIX. Além destas, os funcionários borbônicos do Rio da Prata mandaram organizar e executar as explorações das costas e dos rios patagônicos, sob o comando de Francisco de Biedma e Basilio Villarino (1778-1779), destinadas a permitir o conhecimento, a colonização e a fortificação das regiões ao sul do Rio da Prata contra qualquer tentativa britânica de ali estabelecer bases para o comércio ou a navegação interoceânica. A competição colonial no Atlântico reativou a vitalidade do imperialismo hispânico e sua aspiração de figurar ao lado de seus rivais mais poderosos, além de gerar alguns de seus produtos intelectuais mais genuínos durante a llustração.

\section{Ingleses}

Nesse sentido, o predomínio naval da Inglaterra e da Grã-Bretanha em geral não deve ser considerado apenas em termos de sua presença mais incisiva nos mares em função do número e da potência de seus navios ou do maior desenvolvimento de seus interesses empresariais no ultramar, mas também o desenvolvimento da produção, edição e circulação dos relatos de viagens. Além das inúmeras incursões pela América, pelo Oceano Índico e no Extremo Oriente documentadas na imprensa, os ingleses do século XVII e XVIII realizaram o maior número de circum-navegações registradas no periodo (além daquelas de Francis Drake e Thomas Cavendish, durante o século XVI), executadas em circunstâncias e sob os motivos mais variados: William Dampier (tripulante das expedições piratas, 1683-1691), Woodes Rogers (capitão de uma expedição corsária, 1708-1711, que levava Dampier como piloto), George Shelvocke (capitão de uma expedição corsária entre 1719 e 1722), George Anson (comandante de uma expedição militar, 1740- 
12

SILVERBERG, Robert. The Longest Voyages: Circunnavegations in the Age of Discoveries. Athens: Ohio University Press, 1997.

13

STOYE, James. El despliegue de Europa, 1648-1688. Madrid: Siglo XXI, 1974, capitulos XI e XII.

14

GOSSE, Phillip. Los piratas del oeste: los piratas de Oriente (Historia de la piratería). Buenos Aires: Espasa-Calpe, 1958, capítulo I.

15

An Account of several late Voyages and Discoveries to the South and the North..., London: Welford, 1694 (editada por Tancred Robinson). Tradução castelhana: Un relato de diversos viajes y descubrimientos. Buenos Aires: Eudeba, 2008.

16

A edição existente no Museu Etnográfico é uma tradução francesa do original em inglês sob o título DAMPIER, Guillaume. Nouveau Voyage Autor du Monde Ou I'on decrit en particulier I'Itsme du l'Amerique, plusier Cotes et lles des Indes Occidentales, les Iles du Cap Verd, le passage per Terre del Fuego les Cotes Merdionales du Chili, du Perou et du Mexique ; I' Isle de Guam, Mindanao et autres Phillippines ; les lles Orientales sont pris de Cambodia, de la China, de Formosa, Luzon, Celebes etc., la Nouvelle Hollande, et le Cap de Bonne- Esperance Ou I'on traite des differents territoirs de tous ces Pays, de leurs Ports, des Plantes, des Fruits, etc., des Animaux qu'on y trouve : De Leurs Habitants, de leurs Coutumes, de leur Religion, de leur Governemnt, de leur Negoces, etc. Par Guillaume Dampier Enrichi de Cartes et des Figures. A Rouen héz Jean Baptiste MachuellEcruyere a I'Image $\mathrm{S}$. Jean, MDCCXV. Avec Aprobation et Privilege du Roy. Tomo II, p.275-400.
1744), John Byron (comandante de uma expedição militar, 1764-1766), Samuel Wallis (oficial no comando de uma expedição militar entre 1766 e 1768), James Cook (comandante de duas expedições militares e científicas, 1768-1771 e 1772-1775). ${ }^{12}$

A superioridade marítima britânica, expressa em termos da realização e publicação de todas estas expedições globais, se beneficiava de vários elementos simultâneos surgidos a partir da transformação da sociedade inglesa, bem como das transformações no contexto internacional. Em primeiro lugar, o estabelecimento por Carlos II (1660-1685) da Royal Society de Londres, destinada por alguns dos seus membros a resolver os problemas astronômicos e climáticos que levaram ao aperfeiçoamento da navegação, e que favoreceu, a princípio, a publicação de coleções de viagens sobre rotas menos percorridas ou conhecidas dos ingleses. Em segundo lugar, a formação de uma aliança dinástica com a Holanda contra Luis XIV, impulsionada pela Revolução Gloriosa (1688), que levou ao trono da Inglaterra Guilherme III e sua esposa Mary II Stuart, assegurou o fluxo de informações e modelos organizacionais holandeses que os ingleses empregaram para si também no campo da navegação. ${ }^{13}$ Finalmente, a experiência marítima inglesa foi enriquecida e multiplicada enormemente no Novo Mundo com o aparecimento de um ator social emergido em uma dinâmica de ocupação diferente da tentada até ali: os bucaneiros do Caribe, cuja presença contínua nas ilhas despovoadas da região e seu ataque assíduo ao fluxo espanhol de metais preciosos foram amplamente conhecidos em Europa - mas especialmente na Inglaterra - a partir da publicação da obra de Alexander Exquemelin, The Buccaneers of America (1678) em dois tomos. ${ }^{14}$

A intervenção da ciência moderna no campo da literatura de viagens - consagrada pelo aparecimento de uma coleção de viagens recopilada e organizada por Tancred Robinson, médico do rei e membro da Royal Society ${ }^{15}$ - agregou-se a ampliação da experiência naval e do acervo de literatura de viagens obtido pelo aporte holandês, para desenvolver uma série de observações empíricas feitas pelos piratas do Caribe, especialmente a partir do trabalho do célebre aventureiro William Dampier, em cuja extensa obra de viagens de circum-navegação e exploração do Pacífico destaca-se seu tratado dos ventos, considerado o melhor trabalho sobre a questão anterior ao desenvolvimento da climatologia. ${ }^{16}$

A derrota da França, sempre inimiga da Inglaterra durante as guerras do século XVIII, teve um papel preponderante na projeção universal das viagens inglesas e de sua amálgama entre empresa militar, benefício comercial e avanço científico que os viajantes ingleses ajudaram a consolidar em suas obras. Durante a Guerra da Sucessão Austríaca (1740-1748), a altaneira expedição do almirante inglês George Anson contra espanhóis e franceses nas colônias americanas (1740-1744) não só provocou a admiração dos contemporâneos, como também atraiu a atenção da Europa para os territórios austrais da América do Sul - a Patagônia, os pampas e, em particular, as Ilhas Malvinas, nas quais Anson recomendou aos seus compatriotas que estabelecessem uma base para o controle da passagem interoceânica. 0 naufrágio circunstancial de um dos navios da expedição Anson, The Wager, provocou conflitos entre os sobreviventes cujos efeitos se tornaram públicos no regresso deles à Inglaterra, onde foram chegando em momentos distintos e por rotas diferentes. 0 processo aberto mais tarde sobre o comportamento da tripulação e do capitão não só causou o aparecimento de vários libelos e panfletos dos envolvidos de ampla circulação 
17

Voyage a la Mer du Sud fait par Quelques Officiers Commandants le Vaisseaux Le Wager pour servir de suite de Voyage de George Anson. Traduit de I'Anglais. A Lyon. Chez Les Frères Duplain, Libraires, Grand rue Mercerie. MDCCLVI. Avec Approbation et Privilege du Roi, p.VII-IX.

18

FALKNER, Thomas. A Description of Patagonia and the Adjoining Parts of South America Containing an Account of the Soil, Produce, Animals, Vales, Mountain Rivers, Lakes, etc of these Countries... Illustrated with a New Map of the Southern Parts of America... Hereford. Printed by $\mathrm{C}$. Pough and fold by T. Lewis, Russell Street, Covent Garden, London, 1774. local, mas tornou-se conhecido na França, particularmente interessada em inteirar-se dos pormenores sobre a questão pelo que se pudesse conseguir em termos de informação geográfica ou náutica sobre a região. ${ }^{17}$

Nesse contexto internacional de conflitos entre britânicos, franceses e espanhóis em sua luta por projetar um controle militar e estratégico sobre o Atlântico Sul, apareceu o texto que pode ser considerado o primeiro tratado sistemático sobre geografia, economia e recursos naturais e demográficos do extremo meridional da América. 0 jesuíta britânico Thomas Falkner (1702-1784) proporcionou, em sua singular obra ${ }^{18}$ - cuja primeira edição faz parte dos fundos bibliográficos do Museu Etnográfico uma descrição avançada, brilhante e detalhada do que se tornaria o espaço territorial da Argentina e do Chile.

A condição de sacerdote jesuita de Falkner o libertava de seu compromisso com a monarquia católica da Espanha e da perspectiva calvinista e anticatólica dominante nos principais setores dirigentes de seu país, 0 que the permitiria traçar o que, para ele, seria a solução diplomática e política mais genuína na competição europeia pelos Mares do Sul: uma aliança entre Espanha e Grã-Bretanha contra a França, o que permitiria aos britânicos apossarem-se dos grandes recursos disponíveis nessa região do planeta, que até então se julgava inacessivel, e aos espanhóis desfrutar da segurança e prosperidade desse intercâmbio.

Bem preparado como naturalista e observador das exigências de seu pertencimento à Royal Society de Londres, A Description of Patagonia and the Adjoining Parts of South América, de Falkner, faz parte de um repertório muito maior de trabalhos científicos com que os britânicos estavam se preparando para cumprir seu duplo propósito de constituir uma forma enciclopédica do conhecimento da natureza e uma dominação colonial estendida aos lugares mais remotos do mundo, ambos baseados no sucesso de suas explorações ultramarinas, particularmente em sua longa tradição de circum-navegações.

Assim, o trabalho Falkner visa a apresentar claramente o cenário de seus estudos como um espaço natural e territorial especifico e original, que é possível e necessário conhecer e explorar. Começa, então, a discutir brevemente o projeto apresentado às autoridades britânicas por George Anson para estabelecer uma colônia nas Ilhas Malvinas.

\footnotetext{
Esta consideração (a de Anson) me leva a imaginar que qualquer informação concernente à geografia, aos habitantes e outras peculiaridades das partes mais austrais do continente poderia ser de alguma utilidade pública, e também poderia trazer algum entretenimento para o curioso. De todo modo, havendo começado a preparar-me como uma pessoa que residia a cerca de quarenta anos na América do Sul, e tendo estado dedicado a sobreviver e a fazer cartas do país, consegui fazer um mapa, conforme o que tinha observado, e do que descobri a partir desta relação, aos quais adicionei uma descrição do pais e dos habitantes indígenas. Também menciono algumas das peculiaridades da produção do pais, como seus artigos de comércio ou aplicações médicas. ${ }^{19}$
}

Este parágrafo indica como Falkner tentou inserir o conteúdo de sua obra no estilo das descrições desenvolvido a partir de sua longa experiência em navegações no ultramar e em circum-navegação, na formalização de tal experiência pela Royal Society de Londres, e da predisposição generalizada do público britânico a participar dessa empresa como ator ou leitor. Os territórios mais ao sul da América entravam agora no conhecimento 
BOUGAINVILLE, Louis A. A Voyage round the World Perfomed by Order of His Most Christian Majesty In the Years 1766. 1767, 1768 and 1769 by Lewis de Bougainville Colonel of Foot and Commodore of the Expedition in the Frigate La Bourdeuse and the Store-ship L'Etoile Translated from the French by John Rinhold Forster... London, MDCCLXXII. do público científico e empresarial europeu graças à singular combinação de competição pelos territórios coloniais, ambições comerciais e empresariais, e aspirações políticas e científicas para estabelecer um conhecimento renovado e integral do planeta.

É possivel que o quadro de observações geográficas e produtivas que Falkner apresenta supere os que vinham surgindo desde o olhar distante das equipagens corsárias a partir do século XVI. No entanto, apesar da superioridade de suas observações devido à sua longa permanência local, a obra de Faulkner foi largamente superada pela que consagrou as viagens de James Cook (1728-1779). A consagração de Cook como o maior explorador do século e de suas viagens como as mais extensas e reconhecidas representou não só o reconhecimento político e econômico da Grã-Bretanha como primeira potência naval e comercial, mas envolveu, além disso, um novo conceito da superioridade britânica em termos geográficos e científicos. Uma notável edição da viagem de Cook existente na Biblioteca do Museu Etnográfico - que poderia muito bem ser considerada a realização da disputada enciclopédia geral sobre o Oceano Pacífico que os britânicos arrebataram em projeto e em obra aos seus concorrentes franceses - sob o título de A Journal of a Voyage to the South Sea on His Majesty's Ship The Endeavour Faith fully Translated From the Papers of the Late Sidney Parkinson Draughtsman to Sir Joseph Banks, Bart. in his Expedition with Dr. Solander round the World... And An Appendix Containing an Account of the Voyages of Commodore Byron, Captain Wallis, Captain Chartered, Monsieur Bougainville, Captain Cook, and Captain Clerke, publicado em Londres em 1784 e editado com base nas notas científicas e astronômicas dos naturalistas Joseph Banks (1743-1820) e Daniel Solander (17731782), expõe com toda clareza o interesse alcançado na Grã-Bretanha por viagens interoceânicas e pelo acesso a todas as rotas e pontos estratégicos indispensáveis para executar e assegurar o fluxo de recursos e metais que sustentaram sua superioridade material e intelectual.

0 pastor protestante e naturalista John Reinhold Forster (17291798), que acompanhara James Cook em sua expedição ao Pacífico de 1772 a 1775, descreveu os méritos da exploração britânica ao compará-los com os de Bougainville, cuja tradução em inglês ele dedica aos membros da Royal Society de Londres:

\footnotetext{
Ainda que o senhor Bougainville seja um homem de indubitável veracidade e capacidade, ele tem sido, no entanto, em alguns casos, enganado por falsos informes, ou por parcialidade em favor de sua nação: em algumas notas adicionais corrigimos, tanto quanto podíamos, esses erros, reivindicando parcialmente à nação britânica o respeito que pensamos que o autor tenha tido; porque o amor ao próprio país é, em nossa opinião, muito consistente com a justiça e a boa educação, qualidades que nunca seriam necessárias para um filósofo" (VI-VIII). ${ }^{20}$
}

Os leitores ingleses de Bougainville ficavam cientes de que a viagem do francês era uma obra de interesse para "qualquer companhia" ocupada em estudar as possibilidades materiais e científicas fornecidas pela circunavegação do planeta, mas também eram capazes de perceber o contraste entre os resultados das explorações inglesas e francesas e seus efeitos concretos: a façanha de Bougainville não podia ser comparada às viagens muito mais numerosas dos britânicos ao redor do mundo, e de nenhuma forma igualava-se à verdadeira construção de uma enciclopédia natural da Terra que essa empresa Ihes permitiu concluir. Por isso, e enquanto os 
21

A Voyage round the World in His Majesty's Ship The Dolphin. Commanded by the Honourable Commodore BYRON in which is Contained a faithfull Account of the Several Places, People, Plants, Animales, etc See on the Voyage... The Second Edition, London, MDCCLXVII, p.I. franceses estavam se preparando para navegar o Pacífico pela primeira vez, o comodoro inglês John Byron completava, com o Dolphin, uma nova circum-navegação inglesa em um recorde de tempo não alcançado até então (1764-1766). 0 autor anônimo do relato dessa viagem pedia a benevolência do leitor para seus méritos literários, que julgava escassos, mas ressaltava a objetividade "científica" de seu testemunho, que dirige ao público anônimo e geral, interessado em controvérsias sobre a situação da Patagônia e de seus habitantes:

\begin{abstract}
0 autor desta viagem se dá conta que nem seus conhecimentos nem suas habilidades o farão digno de figurar no Mundo das Letras. Ele não está acostumado a escrever, não tem nenhuma inclinação que o distinga nesse sentido; estando preparado para uma profissão que requer outro tipo de argumento ou instrumentos [diferentes dos] que se usam na imprensa. Após esta declaração, tem a esperança de poder reivindicar a indulgência do leitor, se a conseguisse, porque esta obra se encontra despojada destas elegâncias de estilo, nesta época em que o Gosto e o Discernimento literário são tão entusiasticamente requeridos; seus propósitos, sustento, foram representar a verdade e apresentá-la com certo equipamento, consoante sua natural simplicidade, mas mesmo que nem sequer isso conseguisse, ao menos para a grata curiosidade, e para remover as dúvidas de seus compatriotas sobre alguns assuntos que ultimamente têm causado muitas disputas. 0 curso da obra, no entanto, é tão conciso quanto possivel, e omitiu tantas circunstâncias da viagem e da conduta da tripulação, como não sendo de interesse, não poderia ter respondido a nenhum outro propósito além de aumentar o tamanho e o preço do volume..$^{21}$
\end{abstract}

\section{Franceses}

Os franceses participaram ativamente da experiência ultramarina desde o início, através das explorações de Giovanni da Verrazano (1524-1527) e Jacques Cartier (1534-1541), ambas enviadas no reinado de Francisco I (1515-1547). Muitos homens dessa nacionalidade participaram ativamente da experiência dos bucaneiros, mas não puderam transmitir seus efeitos pela literatura - com exceção, é claro, do próprio Alexander Exquemelin, que chegou até ali como cativo - com a mesma eficácia e resultados semeIhantes aos de seus companheiros do outro lado do Canal da Mancha.

Os franceses começaram a obter as principais conquistas em seus conhecimentos sobre o Atlântico Sul e o Índico a partir da tradução de obras em inglês e holandês sobre o tema. Porém, como resultado de seu confronto com a Inglaterra, os círculos dirigentes e seus marinheiros se viram obrigados a enfrentá-la cada vez mais no mar e, depois da chegada da dinastia dos Bourbons ao trono espanhol, a economia francesa foi gradualmente beneficiada com o tráfico comercial de suas colônias, da qual deslocaram quase completamente os espanhóis no início do século XVIII.

Uma das primeiras experiências para enfrentar os ingleses na supremacia dos mares começou durante a Guerra da Liga de Augsburgo. 0 nobre francês Jean-Baptiste de Gennes recebeu ordem de Luis XIV para comandar uma expedição destinada a explorar a costa da África e da América e penetrar no Oceano Pacífico atravessando o Estreito de Magalhães, para atacar as costas das colônias mineiras da América espanhola. A frota, composta por seis navios e mais de seiscentos e cinquenta homens, partiu de La Rochelle em 3 de junho de 1695 e regressou ao mesmo porto em 21 de abril de 1697. Os navios que integravam a frota eram o Falcão Inglês, de 46 peças de artilharia e com uma tripulação de 260 homens, o Sol da África, de 32 peças de artilharia e 220 homens, o Sedicioso, de 26 peças 
FROGER, François. Relation d'un Vovage de la Mer du Sud, Detrot de Magellan, Bresil, Cayenne, et les Isles Antilles, ou l'on voit les Observations que l'Auteur a faites sur la Religión, Mouers, et Coutumes des Peuples qu'y habitent. En fin, les divers Animaux s'y trouvent du meme que des Fruits et les Plantes qu'y croisent. Par ñe Sr. Froger...A Ámsterdam. Chez Honoré et Chatelet, MDCCXV. de artilharia e 140 homens, a corveta Felicidade, de 8 peças de artilharia e 40 homens, e as urcas Comilona, de 10 peças de artilharia e 40 homens, e Fértil, de apenas 4 peças e 20 homens. Tratava-se, como se pode ver, de uma frota considerável em embarcações, homens e armamentos, em todo caso bastante superior à que costumavam mobilizar os ingleses, rivais dos franceses nos mares e na guerra.

Esta presença tão significativa dos franceses no Atlântico se explica menos pelas ambições coloniais do soberano francês que por uma crescente consciência do Rei Sol de que seus planos militares e religiosos de hegemonia católica na Europa se enfrentariam com a hegemonia inglesa e holandesa nos mares. Os antagonismos político-religiosos e as aspirações territoriais de Luis XIV de estender seu domínio para além do Reno combinaram-se no estopim da guerra, na qual a frota de De Gennes entrava como parte como uma tentativa de ataque naval ao comércio de ingleses e espanhóis. A expedição rendeu poucos sucessos militares no Atlântico: algumas capturas de navios e desembarques na costa africana. Chegando ao Cabo Vírgenes após alguns incidentes náuticos, a esquadra entrou no Estreito e arribou em Puerto Hambre, onde fez contato com os nativos. Um pouco mais adiante, as crescentes dificuldades causadas por ventos contrários e pelo frio inclemente dissuadiram o comando da expedição de continuar em seu intento. Na volta, a frota francesa ancorou na Baía de Todos os Santos, no Brasil, antes de dirigir-se a Caiena, colônia francesa na costa da Guiana. Nas águas do Caribe, arribaram na Martinica, outra base francesa, que usaram para realizar mais algumas incursões contra navios ingleses. Depois, passando por Guadalupe, os navios seguiram para a França.

Como pode ser deduzido a partir da experiência de De Gennes, os franceses procuraram, de algum modo, recriar a experiência dos bucaneiros, mas com base na iniciativa estatal, ou seja, enviando uma armada autorizada pelo rei para repetir as operações piratas que os bucaneiros realizavam por sua própria conta no Caribe e no Pacífico. 0 cronista da expedição, François Froger, que incorporou à sua obra mais de trinta mapas e gravuras sobre peixes, plantas, animais, instituições e costumes dos povos da África e da América visitou ${ }^{22}$, confessou claramente:

Até o ano de 1686, alguns flibusteiros da Ilha de Santo Domingo, que poderiam ser bastante inimigos da paz, depois de haver fustigado por muitos anos as costas de Caracas, da Nova Espanha e de Cuba sem conseguir fortuna, resolveram ir para as [costas] do Mar do Sul, que sabiam que eram mais ricas e menos fortificadas. Se Ihes apresentavam, de fato, duas passagens, uma por terra e a outra pelo Estreito de Magalhães. A primeira, que era mais curta, havia sido utilizada por alguns outros flibusteiros, mas nela havia dois grandes obstáculos: o primeiro, serem atacados ao passarem por ali pelos índios, que às vezes estão em guerra e às vezes em paz com os espanhóis; o outro, o de encontrar no dito mar os navios necessários para as suas ações. A passagem pelo Estreito de Magalhães parecia mais segura, entraram em número de quatrocentos e vinte homens no Mar do Sul e temeram pelos frequentes desembarques que fizeram em diferentes lugares, e pelo grande número de navios ricamente carregados que capturaram e dos quais, todavia, obtiveram pouco botim (...).

Todos os flibusteiros, depois de regressarem ao Mar do Norte, sonham em retirarse com sua pequena fortuna (...) mas houve entre eles quatro ou cinco que não puderam limitar-se a tão pouca coisa, resolvendo fazer uma segunda viagem (...). Um deles, chamado Marcety, dirigiu-se a Monsieur de Gennes, que sabia ser muito empreendedor. Monsieur de Gennes escutou seu projeto e foi para Paris a fim de apresentar as consequências à Corte, oferecendo-se para executá-lo caso se decidisse realizá-lo. 
FROGER, François. A Relation of a Voyage made into the years 1695, 1696, 1697 on the Coast of Africa, Straights of Magellan, Brasil, Cayena and the Antillas, by a Squadron of French Men of War, under the Command of M. De Gennes, Londres, 1698.

GRAND-PIERRE, Dralsé. Relation de Divers Voyages dans I'Afrique, I'Amerique et aux Indes Occidentales. Avec la description du Rouyame de Juda, et quelques particulariez touchants a la vie du Roi regnant.La relatiom d'un Isle nouvellement habité dans le Detroit de Malaca en Asie. Avecl'Histoire du deux Princes de Golconde, MDCCXXVI. Sobre a viagem de Dralse de GrandPierre ao Prata, ver também RIPODAS ARDANAZ, D. (ed.). Viajeros al Río de la Plata, 1701-1725. Buenos Aires: Academia Nacional de la Historia, 2002, estudo preliminar, p.13-76.
A proposta de Monsieur de Gennes foi recebida com toda a acolhida que se podia esperar; o rei o proveu de navios à sua escolha. ${ }^{23}$

A importância da expedição de De Gennes e da obra de Froger podem ser vistas no fato que os próprios britânicos a traduziram para sua língua no ano seguinte e a colocaram ao lado das dos bucaneiros que floresciam por volta desse ano de $1699 .{ }^{24}$ Mesmo sem ter alcançado seus objetivos, os resultados atraíram o merecido interesse que tinham, por tratar-se de uma experiência no Estreito de Magalhães que devia ser levada em conta nas empresas posteriores.

0 Museu Etnográfico - bem como outras bibliotecas em Buenos Aires - preserva um raro exemplar da segunda edição do livro de Froger, que documenta os esforços da França para fornecer aos bucaneiros informações sobre como obter vantagens no ultramar. Um testemunho similar, que se aproxima das experiências inglesas na América, é o do aventureiro e comerciante Dralsé de Grand Pierre. Ele estava ligado aos círculos do comércio atlântico de matérias primas, escravos e manufaturas que a França controlava no lugar da metrópole espanhola. Grand Pierre realizou várias viagens para as costas da América, África e Caribe, enquanto se desenrolava a Guerra de Sucessão Espanhola na Europa. A partir de suas experiências, publicou uma Relation des Divers Voyages dans I'Afrique, I'Amerique et aux Indes Occidentale, surgida em 1718 e reimpressa em 1726 (edição da obra existente no Museu Etnográfico) e $1728^{25}$, o que documenta o interesse que chegou a despertar. Embarcado em 1707 para introduzir escravos, Grand Pierre chegou a Buenos Aires no navio A Esfera e conheceu, assim, as costas americanas do Atlântico Sul. Em sua dedicatória ao Conde de Toulouse, Almirante do Reino, Grand Pierre justifica a importância de sua obra:

\section{Tantas obras desta natureza têm vindo a público, que eu temeria que a minha não pudesse chegar até vós, Senhor, se a bondade de Vossa Alteza Sereníssima não abrisse os olhos. Recomendável, em princípio, é convencer-se de que atrai todos os corações. Deixa o campo aberto àqueles que tem a felicidade de aproximar-se.}

0 livro de Grand Pierre - curto, divertido, de leitura rápida - dirigiase a um público amplo e aspirava preencher essa lacuna de autores que escreveram no impulso de uma experiência que não é do funcionário, do chefe militar ou do missionário, autores de boa parte das relações dedicadas a instruir os leitores, sobretudo os do governo, sobre as terras do ultramar, especialmente as de Quebec e Louisiana, na América do Norte.

No entanto, a dinâmica social que impulsionava a expansão ultramarina francesa não promovia o surgimento de aventureiros individuais ao gosto dos ingleses. A realização do projeto de travessia do Estreito de Magalhães demoraria, bem como o surgimento de uma indústria editorial que promovesse a leitura dos relatos de viagem a fim de estimular mais ativamente a participação nos mesmos. Naquela altura, os franceses fracassaram em ambos os intentos: não conseguiram circum-navegar o globo como tantas vezes haviam feito os espanhóis, os ingleses e os holandeses, e tampouco concluíram a façanha de renovar o conhecimento geográfico e natural e seus métodos, como fizeram as obras de James Cook e Thomas Falkner. Seria necessário esperar mais de meio século para que a expedição Louis Antoine de Bougainville (1766-1769) completasse a primeira e tardia circum-navegação do mundo, provocando, desta vez, um notável sucesso editorial e intelectual com a publicação de seu diário de viagem. No 
entanto, a presença de François Froger na expedição de De Gennes como um jovem engenheiro, artista e observador da natureza, autor de mapas, desenhos e gravuras, antecipou a atividade de numerosos especialistas franceses nestas disciplinas, tais como a do muito mais célebre e renomado engenheiro Amédée François Frezier (1682-1773) que publicou, em 1715, uma Relation du voyage de la mer du Sud, aux côtes du Chili, du Pérou et de Brésil, fait pendant les années 1712, 1713, et 1714, e a de seu antagonista, o frade botânico e naturalista Louis Feuillé (1660-1732), autor do Journal des observations physiques, mathématiques et botaniques, Faites par l'ordre du Roy sur les Côtes Orientales de l'Amérique Méridionale, Ct dans les Indes Occidentales, depuis l'année 1707, jusques en 1712, publicado em 1714 em dois volumes. Uma marca distintiva do trabalho de Froger é a profusão de excelentes gravuras e planos que visam documentar melhor a viagem e parecem enfatizar, também, seu próprio deslumbramento pelas espécies vegetais e animais, os tipos humanos e as paisagens exóticas que ele conheceu em sua viagem pela África e América. Parece evidente que Frezier, Feuillé e seus seguidores viram na obra de Froger uma fonte de inspiração para suas próprias viagens e observações. A narrativa da viagem de De Gennes foi publicada em francês em 1698 e novamente em 1715, quando, após o fim da Guerra de Sucessão Espanhola, tornou-se cada vez mais indispensável o conhecimento das rotas e costas da América do Sul, para manter com essa região o comércio ativo do qual os espanhóis se veriam deslocados.

Foi necessário o fim das hostilidades anglo-francesas na Guerra dos Sete Anos (1756-1763), de resultados catastróficos para a França, para que, após a humilhante cessão de suas possessões coloniais na Louisiana, no Canadá e na Índia aos seus rivais britânicos, os franceses encontrassem, na possibilidade de uma grande empresa de circum-navegação, curar as feridas do orgulho dinástico causadas pela derrota. Assim, então, Louis Antoine de Bougainville deveria, por ordem real, "devolver" as Ilhas Malvinas à coroa espanhola - que ela mesma havia colonizado - e, mais tarde, completar a rota do que se converteria na primeira circum-navegação francesa. 0 patrocínio oficial e a primazia ilustrada das letras da França sobre o resto do continente deram à empresa de Bougainville uma repercussão internacional cuja causa seria atribuída à singularidade de suas observações e relatórios anteriores à sua execução, tantas vezes feita, durante séculos, por espanhóis, ingleses e holandeses. 0 surgimento da obra resultante da expedição assume, assim, todas as dívidas francesas acerca do conhecimento do mundo, e seria apresentada a Luis XV como fruto da fidelidade e do serviço ao soberano e ao público leitor, agora identificado com a Humanidade, de acordo com os modelos científicos e literários da llustração:

A viagem da qual serei responsável, é a primeira dessa espécie empreendida pelos franceses e executada pelos navios de Vossa Majestade. 0 mundo inteiro já Ihe deve o conhecimento do formato da Terra. Aqueles dos vossos súditos a quem foi confiado este importante descobrimento, escolhidos entre os mais ilustres sábios da França, determinaram as dimensões da Terra.

\begin{abstract}
A América, de fato, descoberta e conquistada, a rota marítima aberta para as Índias e as Molucas, são prodígios da coragem e êxito sem dúvida pertencentes aos espanhóis e portugueses (...). Incentivados pelo seu exemplo, navegadores ingleses e holandeses descobriram novas terras, e enriqueceram a Europa, enquanto a ilustravam.
\end{abstract}

Mas este tipo de primazia e de primogenitura em matéria de descobrimentos, não impediu que os navegadores franceses reivindicassem com justiça uma parte da glória ligada a estas brilhantes, porém penosas, empresas. Muitas regiões da América 
26

BOGAINVILLE, Louis Antoine. Voyage autour du Monde par la Fragate du Roi la Bourdeuse et la Flûte L'Etoile en 1766, 1767, 1768 et 1769. A Paris. Chez Saillant e Nyon, Libraires, rue $S$, Jean-de-Beauvais De I'Imprimiere de la Bretton, premier Imprimeur du Roi. MDCCLXXI. Avec Approbation et Privilege du Roi.

27

KOSSOK, Manfred. El Virreinato del Río de la Plata. Buenos Aires: Hyspamérica, 1986. foram descobertas por súditos valorosos dos Reis Vossos Ancestrais (...). Diferentes causas, tanto interiores como exteriores pareceram suspender, desde então, nesta perspectiva, o gosto e a atividade da nação.

Vossa Majestade tem procurado se beneficiar dos descansos da paz para procurar a Geografia de conhecimentos úteis para a Humanidade. Sob Vossos auspícios, entramos na carreira, as provas de todo o gênero nos vem encontrar a cada passo, a paciência e zelo que perdemos. Esta é a história dos nossos esforços, que me atrevo a apresentar a Vossa Majestade. Vossa aprovação proporcionará o êxito. ${ }^{26}$

Apesar de seus esforços, a publicação das viagens de Cook, Byron e Falkner já vinham adiantando todos os dados que tornavam tão atrativa a rota dos Mares do Sul, seus portos e potenciais recursos. E eles sabiam que essas rotas e esses portos estavam dentro dos domínios austrais da Coroa espanhola.

\section{Espanhóis}

Na verdade, o que estava em questão no final do século XVIII era a integridade dos domínios espanhóis no extremo sul da América do Sul, domínios esses pouco conhecidos por sua própria metrópole. A notável difusão da obra de Falkner e seu sucesso nos círculos de leitores europeus é considerada, por vezes, uma causa direta da iniciativa espanhola de renovar sua política no Atlântico Sul e da criação do Vice-Reino do Rio da Prata com um caráter de bastião imperial, à espera de um iminente ataque britânico pelas autoridades peninsulares. A coroa espanhola, afetada pela recente derrota na Guerra dos Sete Anos (1756-1783), pensava em um pronto assalto dos britânicos a suas colônias rio-platenses e mirava com receio 0 estabelecimento de sua aliada França nas Ilhas Malvinas, dirigido por Louis Antoine Bougainville. ${ }^{27}$

0 interesse hispânico pela definição, conhecimento e defesa de seus territórios coloniais na América meridional foi a ocasião, para o Estado espanhol, de realizar uma de suas grandes etapas de crescimento econômico e político. A corte madrilenha encarou, efetivamente, várias tentativas de conhecer e colonizar as remotas terras patagônicas e magalânicas, de fato descobertas por um marinheiro a serviço de Castela, Fernão de Magalhães. Porém, a continuidade dessas tentativas fora afetada pela descoberta de rotas alternativas que a tornavam menos necessária (em particular, a que Ihes permitia circular pelo Pacífico entre suas possessões americanas e asiáticas, conectando-as diretamente desde a metrópole) e a condição inóspita do clima e dos solos da região, que impediam a manutenção de qualquer assentamento europeu com base na agricultura (como o haviam experimentado tão catastroficamente os povoadores das colônias que Pedro Sarmiento de Gamboa tentou fundar no Estreito em 1584, Nombre de Jesus e Real Don Felipe). A presença regular de navios estrangeiros holandeses e ingleses na região era facilmente constatada pelas autoridades espanholas, que confiavam em neutralizá-las, provavelmente, pela escassez de recursos e ausência de portos locais - pelo menos até 1640, data da perda da unidade peninsular que havia permitido aos espanhóis controlar também os portos do Brasil, ao menos nominalmente.

Claramente, ao que parece, a Espanha percebeu com agudeza a mudança nas condições internacional ao longo do século XVIII, e as regulares navegações inglesas de Rogers, Shelvocke, Anson e Cook, assim como a circulação de notícias fornecidas por Falkner, Ihe fizeram abandonar sua 
28

Sobre os objetivos científicos e geográficos da expedição de Alejandro Malaspina, ver especialmente FIGUEROA, Marcelo. Natural History, Collecting Practices and Colonial Power. The Malaspina expedición in the River Plate. Internacional Seminar on the History on the Atlantic World, 1500-1825, Harvard University, 2009.

29

MALASPINA, Alejandro; BUSTAMANTE Y GUERRA, José. Viaje político cientifico alrededor del mundo por las corbetas Descubierta y Atrevida al mando de los capitanes de navío... desde 1789 a 1794. Con una introducción por Don Pedro de Novo y Colson. $2^{\text {a }}$ edição. Madrid: Viuda e Hijos de Abienzo, 1885

30

NODAL, Bartolomé G. y Gonzalo. Relación del Viaje que por orden se Su Majestad y acuerdo del Real Consejo de Indias hicieron los capitanes... hermanos naturales de Pontevedra, al descubrimiento del Estrecho Nuevo de San Vicente que hoy es nombrado de Maire y reconocimiento del de Magallanes... Lleva añadido las derrotas de la América Occidental de unos Puertos a otros, que dio a luz el teniente de navio de la Real Armada, Don Manuel de Eclavelar. Cádiz: Imprenta de Manuel Espinosa de los Monteros, 1766.

31

Relación del último viaje al Estrecho de Magallanes de la fragata de S. M. Santa María de la Cabeza de los años 1785 y 1768... Trabajada por orden del Rey. Madrid: Viuda de Ibarra, 1788.

32

DE ANGELIS, Pedro. Colección de Obras y Documentos relativos a la Historia Antigua y Moderna del Río de la Plata. Buenos Aires: Imprenta del Estado, 1836-1837. 7 tomos. 0 tomo VI reúne os informes de Biedma y Villarino. inatividade na área. É neste contexto que é preciso situar as grandes narrativas de viagens científicas: a de Félix de Azara (1781-1801) - inicialmente destinado a fixar os limites dos impérios espanhol e português na América do Sul, após a expulsão dos lusitanos de Colônia do Sacramento e da fundação do Vice Reinado do Rio da Prata, em 1776 - e a mais importante empresa ultramarina da monarquia espanhola do século XVIII, a expedição de Alejandro Malaspina (1789-1794). ${ }^{28}$ Os resultados de ambas foram exaustivas descrições geográficas, botânicas, zoológicas e econômico-produtivas, muito procuradas pelo público político e científico da época. A Biblioteca do Museu Etnográfico de Buenos Aires tem uma edição francesa do texto de Azara, Voyages dans l'Amerique Meridional par don... comisaire et commandant dans les limites espagnoles dans le Paraguay (Paris, 1809) e uma espanhola muito mais tardia da célebre edição de Malaspina da Viaje político científico alrededor del mundo por las corbetas Descubierta y Atrevida ${ }^{29}$. Por outro lado, encontra-se na Biblioteca o relato da expedição dos irmãos Bartolomé e Gonzalo Garcia de Nodal ao Estreito de La Maire e ao de Magalhães ${ }^{30}$, claramente voltada aos mesmos fins de exploração que tornaram possível prever o avanço de expedicionários inimigos na região e na qual o Estreito de Le Maire, descoberto pelos holandeses no início do século XVII, é chamado de "Estreito Novo de San Antonio". Outra tentativa de aperfeiçoar o conhecimento do Estreito de Magalhães foi feita pelo capitão de navio Antonio Córdoba Lazo, no comando da fragata Santa Maria de la Cabeza, entre 1785 e 1786, cujo diário de viagem, publicado em 1788, também faz parte do acervo bibliográfico do Museu Etnográfico. ${ }^{31}$

Tanto a obra de Azara como a de Malaspina tiveram ampla repercussão entre os leitores europeus e acabaram por se constituir em obras de referência para o conhecimento do Rio Prata e do Atlântico Sul durante a primeira metade do século XIX. Por outro lado, outros trabalhos de exploração realizados pelos espanhóis ficaram a cargo das autoridades vice reinais de Buenos Aires e não alcançaram difusão no cenário europeu: os reconhecimentos de costas e rios patagônicos feitos por Francisco de Biedma e Basilio Villarino (1778-1779) para colonização e fortificação contra a ameaça de eventuais instalações britânicas foram finalmente recopiladas no cenário local riopratense por Pedro de Angelis em sua miscelânea documental Colección de Obras y Documentos relativos a la Historia Antigua y Moderna del Río de la Plata, publicada entre 1836 e 1837, no início do segundo governo de Juan Manuel de Rosas. ${ }^{32}$

\section{Breves considerações finais}

Este trabalho tentou mostrar como a luta pelo domínio dos mares e do comércio colonial em nível global durante o século XVIII cuja expressão mais genuína, nessa altura, era a circum-navegação do globo - transformou significativamente a perspectiva dos europeus sobre o papel das viagens em relação com as nascentes ciências naturais e, em particular, o conhecimento do Atlântico Sul e dos territórios americanos adjacentes.

Neste sentido, e embora a superioridade britânica fosse evidente após a Guerra dos Sete Anos, bem como seus progressos tanto na realização das empresas de navegação como na multiplicação do conhecimento da natureza, não resta dúvida de que, em seus respectivos contextos geopolítico e material, França e Espanha elaboraram, no desenvolvimento do mesmo processo de competição contra sua rival, alguns dos maiores êxitos 
de sua produção científica e literária em relação à sua relativa marginalidade no contexto europeu.

No entanto, não foram as circunstâncias econômicas, diplomáticas e militares as únicas que impulsionaram o predomínio britânico: certas condições internas, especialmente o peso das empresas editoriais e a rápida tradução de relatos de viagens, favoreceram a participação mais ativas de atores sociais diversos, acima dos interesses mais especificamente estatais, que predominaram, sem dúvida, nos comportamentos da França e da Espanha frente às mudanças experimentadas no interesse das sociedades europeias pelos territórios ultramarinos.

A influência da expansão ultramarina durante o século XVIII foi decisiva para a construção da ciência moderna do século seguinte. As referências às obras de Cook, Forster e Parkinson, mas também às de Bougainvile, Azara e Malaspina, tornaram possivel uma concepção de mundo natural e de mundo humano que impulsionaria a renovação no campo da biologia - com o surgimento da teoria da evolução - e o surgimento das ciências sociais.

0 fato de que a obra de Azara constituiu uma das principais fontes de conhecimento da natureza riopratense para Charles Darwin durante sua viagem ao redor do mundo com o Beagle, ou que até quase o final do século XIX os únicos trabalhos confiáveis sobre as costas e rios patagônicos continuavam a ser, para Estanislao Zeballos, as expedições de Biedma e Villarino, destaca o peso fundamental que a geografia e a ciência tiveram para a história dos séculos XIX e XX na Argentina e em vários outros lugares do mundo, onde os testemunhos de homens como Cook, Malaspina ou Bougainville permaneceram, por muito tempo, os únicos e frágeis emblemas do imperialismo europeu presentes ali. 